\title{
Bathymetry and Seabed Morphology Study for Determination of ASDP Shipping Line in Tanjungsau Island Waters, Batam
}

\author{
Melanie Rizky Hanuransyah $^{1^{*}}$, Alfi Satriadi ${ }^{2}$, Kunarso $^{2}$, Eka Bathin Putra $^{3}$, Jarot Marwoto ${ }^{2}$ \\ ${ }^{I}$ Program Sarjana Departemen Oseanografi, Fakultas Perikanan dan Ilmu Kelautan \\ ${ }^{2}$ Oceanography Department, Faculty of Fisheries and Marine Science, Diponegoro University \\ Prof. H. Sudarto Street, SH., Tembalang, Semarang, East Java. 50275 Phone/fax (024)7474698 \\ ${ }^{3}$ Tanjungpinang I Navigation District, Navigasi Street, Kijang, Tanjungpinang, Riau Islands \\ Phone. (0771) 463397 / Fax. (0771) 463398 Riau Islands 29151 \\ Email:*merzsyah@gmail.com
}

\begin{abstract}
Tanjungsau Island Waters as the main gate of shipping line between Bintan Island and Batam need more attention for its shipping safety. The purpose of this research is to review the seabed morphology of Tanjungsau Island Waters, Batam for determination of ASDP shipping line. This research had been conducting from 3 rd to 5th of Jule 2018 in The Tanjungsau Island Waters, Batam. The used data are depth measurement by singlebeam echosounder type Ceducer Pro, tidal data, ship draft, and Digital Map of Indonesia Sea edition 2013 Vol. 49 published by TNI-AL DISHIDROS. Data had processed by using ArcGIS 10.3 and Surfer 9 software to generate the bathymetry contour and the 3D model of seabed morphology. The result indicates that the depth ranged between -1,69 $m$ to $-17,58 \mathrm{~m}$. The bathymetry contour map shows seabed morphology is a continental shelf. Based on the slope calculation, Tanjungsau Island Waters not only include flat category between 1,08\% - 1,58\% but also having a slope area worth 2,59\%. The right ASDP shipping line from Bintan Island to Batam has the minimum depth -5,32 $\mathrm{m}$ with the largest ship draft which can enter approximately 4,788 m.
\end{abstract}

Keywords: Bathymetry, Seabed Morphology, Ship Lane, Tanjungsau Island Waters

\section{PRELIMINARY}

The effective and efficient sea transportation system help Indonesia to manifest our national ideals as the world maritime axis. It has supported by the role of PT. ASDP Indonesia Ferry (Persero) as the inter-island public transportation supply infrastructure in Indonesia. Destination cruise from The Port of ASDP Tanjung Uban-Bintan to The Port of ASDP Telaga Punggur-Batam can be accessed by distance around 10 miles (Sihombing et a.1., 2015). Therefore, information about the ocean depth (bathymetry) and the latest hydrooceanographic condition have needed for shipping safety.

Based on data from the Central Statistics Agency (2018), Riau Islands Province has $16.403,44 \mathrm{~km}^{2}$ land area and $415.231,79 \mathrm{~km}^{2}$ ocean area, so that $96.2 \%$ from the total area consist of oceans. It indicates that sea in Riau Islands is the main access to progress the region. So far, there have no official publications about bathymetry survey in Tanjungsau Island Waters as the main connecting gate between Bintan and Batam Island. Beside that, around Tanjungsau Island there is a sandbar that only appears on low tide (Tanjungpinang I Navigation District, 2018). It certainly a threat for the safety of sailing ships.

To answer these challenges, it is necessary to conduct a research about bathymetry survey which is a series of activities to produce seabed image using acoustic waves. Therefore, this research intends to examine the seabed morphology of Tanjungsau Island Waters as consideration in determination of the right ASDP line for shipping safety.

\section{MATERIAL AND METHOD}

\section{Research Material}

The material that used in this research are the bathymetry and tidal data on $3^{\text {rd }}-5^{\text {th }}$ July 2018 in Tanjungsau Island Waters. The supporting data are Google Earth satellite imagery of Tanjungsau Island in 2018, tidal data from TNI-AL DISHIDROS in July 2018, draft ship data from UPP Class I Tanjung Uban-Riau Islands, and Indonesian Digital Sea Map No.49 2013 Edition DISHIDROS publication 1:25.000 scale.

\section{Research method}

In this research, bathymetry measured by Singlebeam Echosounder with a quantitative method according to the map of sounding lane which has made. 


\section{Data Collection Method}

This research started by tidal observation using tide pole at Telaga Punggur Old Village precisely located in coordinate $1^{\circ} 01^{\prime} 58$ "LU and $104^{\circ} 57^{\prime} 02^{\prime \prime}$ BT. On $4^{\text {th }}$ July 2018 , bathymetry data had been recording use Singlebeam Echosounder type Ceducer Pro from the "Nongsa" Ship belonging to Tanjungpinang Class I Navigation District.

\section{Data Processing and Analysis Method}

Tidal

The tidal data then processed using Admiralty method to obtain the value of $M S L, L L W L$, and $H H W L$. According to Ongkosongo (1989), these following equations have used to determine tidal components:

1. MSL (Mean Sea Level) $M S L=A\left(S_{0}\right)$

2. $L L W L$ (Lowest Low Water Level)

$L L W L=A\left(S_{0}\right)-\left[A\left(M_{2}\right)+A\left(S_{2}\right)+A\left(N_{2}\right)+A\left(K_{l}\right)+A\left(O_{1}\right)+A\left(P_{1}\right)+A\left(K_{2}\right)+A\left(M_{4}\right)+A\left(M S_{4}\right)\right]$

3. $H H W L$ (Highest High Water Level)

$H H W L=A\left(S_{0}\right)+\left[A\left(M_{2}\right)+A\left(S_{2}\right)+A\left(N_{2}\right)+A\left(K_{l}\right)+A\left(O_{l}\right)+A\left(P_{l}\right)+A\left(K_{2}\right)+A\left(M_{4}\right)+A\left(M S_{4}\right)\right]$

4. $Z_{0}$ (Neap Face)

If each tidal component was known for its amplitude, the neap face be sought by this equation:

$Z_{0}=M_{2}+S_{2}+N_{2}+K_{1}+O_{1}+P_{1}+K_{2}+M_{4}+M S_{4}$

5. $F$ (Value of Formzhal)

Formzhal is a determinant of tidal type that described as follows: $F=\underline{K}_{1}+\underline{O}_{l}$

$$
M_{2}+S_{2}
$$

\section{Bathymetry}

According to Soeprapto (2001), bathymetry must be corrected to the sea water level (MSL, $\left.Z_{0} T W L t\right)$ at the measurement time and corrected for the sinking distance of the transducer (transducer correction) to obtain the actual depth.

The correction of tides be sought by this equation:

Information:

$$
r t=T W L t-\left(M S L+Z_{0}\right)
$$

$r t \quad$ : An amount of correction to the depth measurement at time $\mathrm{t}$.

TWLt : True water level at time t.

$M S L$ : The average of sea level.

$Z_{0} \quad$ : Neap face below $M S L$.

The above equation produces a correction tide, then calculate the actual depth using this formula:

$$
D=d T-r t
$$

Information:

$D$ : Real depth.

$d T$ : The depth of transducer correction.

$r t$ : The correction of tide.

Then, the corrected depth processed by ArGIS software 10.3 with Topo to Raster method so obtained the depth contour and labeled using Contour option.

\section{Seabed Slope}

The classification of seabed slope based on Van Zuidam Classification (1985) by calculated the slope use equation number 8 . The visualization of cross section will be displayed on the map by ArcGIS 10.3.

$$
S=\frac{(n-1) x I c}{\Delta h} \times 100 \%
$$

Information:

$S$ : Slope value (\%).

$\Delta h$ : Horizontal distance $(\mathrm{m})$.

Ic : Contour interval.

$\mathrm{n}$ : The number of contours. 
Table 1. Classification of Seabed Slope (Van Zuidam, 1985)

\begin{tabular}{ccc}
\hline Characteristic & Class of slope (\%) & Morphology $\left(^{\circ}\right)$ \\
\hline Flat to almost flat & $0-2 \%$ & $0-2^{\circ}$ \\
Slightly sloping or sloping & $2-7 \%$ & $2-4^{\circ}$ \\
Sloping with a high size or bumpy & $7-15 \%$ & $4-8^{\circ}$ \\
Slightly steep & $15-30 \%$ & $8-16^{\circ}$ \\
Steep & $30-70 \%$ & $16-35^{\circ}$ \\
Very Steep & $70-140 \%$ & $35-55^{\circ}$ \\
Extremely Steep & $>140 \%$ & $140 \%>55^{\circ}$ \\
\hline
\end{tabular}

\section{Shipping Line}

The Tanjungpinang Class I Navigation District (2018) determines the shipping line based on consideration of the value of bathymetry record, sea map and draft ship data. Furthermore, UKC value and the maximum draft ship calculated with the minimum depth of agreed sounding lane.

$$
\begin{aligned}
U K C & =10 \% \times \text { D.min } \\
\text { Draft Max. } & =\text { D.min }- \text { UKC } \\
l & =1.5 \times \text { Loa }
\end{aligned}
$$

Information:

$U K C$ : Under keel clearance (m).

D.min : Minimum depth (m).

l. $\quad$ : The width of the planning line $(\mathrm{m})$

Loa : Length over all (m).

\section{RESULT}

Tidal

Based on tidal data analysis, the value of mean sea level (MSL) is $150 \mathrm{~cm}$, highest high water level (HHWL) $309 \mathrm{~cm}$, lowest low water level (LLWL) $-9 \mathrm{~cm}$, and the neap face $\left(Z_{0}\right)$ is $159 \mathrm{~cm}$. The value of formzahl 1,066 shows that the tidal type of Tanjungsau Island Waters is a dominant semidiurnal mixed tide.

\section{Bathymetry}

The result of bathymetry measurement that have corrected with vertical reference field (chart datum), true water level at the time of measurement and the depth of transducer to obtain the actual. This following are the

\begin{tabular}{|c|c|c|c|c|c|c|c|c|c|c|}
\hline $\begin{array}{c}\text { Point of } \\
\text { Depth }\end{array}$ & Longitude & Latitude & $\begin{array}{l}\text { Depth from } \\
\text { The Tool (m) }\end{array}$ & $\begin{array}{c}\text { Tranducer } \\
\text { (m) } \\
\end{array}$ & $\begin{array}{l}d T \\
(\mathbf{m}) \\
\end{array}$ & $\begin{array}{c}T W L t \\
\text { (m) }\end{array}$ & $\begin{array}{r}M S L \\
(\mathrm{~m}) \\
\end{array}$ & $\begin{array}{l}Z 0 \\
(\mathbf{m}) \\
\end{array}$ & $\begin{array}{c}r t \\
(\mathrm{~m})\end{array}$ & $\begin{array}{c}\text { The Actual Depth } \\
\text { (m) } \\
\end{array}$ \\
\hline 1 & $01^{\circ} 03^{\prime} 55^{\prime \prime}$ & $104^{\circ} 09^{\prime} 41^{\prime \prime}$ & -7.05 & -0.5 & -7.6 & 2.09 & 1.5 & 1.59 & -1 & -6.55 \\
\hline 10 & $01^{\circ} 04^{\prime} 12^{\prime \prime}$ & $104^{\circ} 10^{\prime} 07^{\prime \prime}$ & -4.37 & -0.5 & -4.9 & 2.09 & 1.5 & 1.59 & -1 & -3.87 \\
\hline 100 & $01^{\circ} 04^{\prime} 04^{\prime \prime}$ & $104^{\circ} 09^{\prime} 33^{\prime \prime}$ & -2.19 & -0.5 & -2.7 & 2.09 & 1.5 & 1.59 & -1 & -1.69 \\
\hline 1.000 & $01^{\circ} 04^{\prime} 03^{\prime \prime}$ & $104^{\circ} 09^{\prime} 41^{\prime \prime}$ & -15.55 & -0.5 & -16 & 2.09 & 1.5 & 1.59 & -1 & -15.05 \\
\hline 10.000 & $01^{\circ} 04^{\prime} 17^{\prime \prime}$ & $104^{\circ} 09^{\prime} 5^{\prime \prime}$ & -5.67 & -0.5 & -6.2 & 1.89 & 1.5 & 1.59 & -1.2 & -4.97 \\
\hline 20.000 & $01^{\circ} 04^{\prime} 37^{\prime \prime}$ & $104^{\circ} 10^{\prime} 34^{\prime \prime}$ & -12.27 & -0.5 & -13 & 2.04 & 1.5 & 1.59 & -1.05 & -11.72 \\
\hline 26.222 & $01^{\circ} 04^{\prime} 37$ & $104^{\circ} 10^{\prime} 34^{\prime \prime}$ & -14 & -0.5 & -15 & 2.04 & 1.5 & 1.59 & -1.05 & -13.45 \\
\hline
\end{tabular}
example of randomly selected sea depth corrections:

Table 2. Data Correction of Sea Depth

\section{Seabed Slope}

Through a bathymetric contour map, a plot line can be drawn to determine cross section of the seabed morphology to the representative depth profile (Figure 1). Cross section made with the exagration scale appropriately vertical scale $=20 \mathrm{x}$ horizontal scale. Withdrawal of cross-sectional lines can describe the density of contour bathymetry by calculating the slope. The result of drawing 4 cross section line plots then calculate and determine the type of its seabed slope according to Van Zuidam Classification. This following are visualization of cross section line for its seabed slope along with the calculation and the shipping line design: 

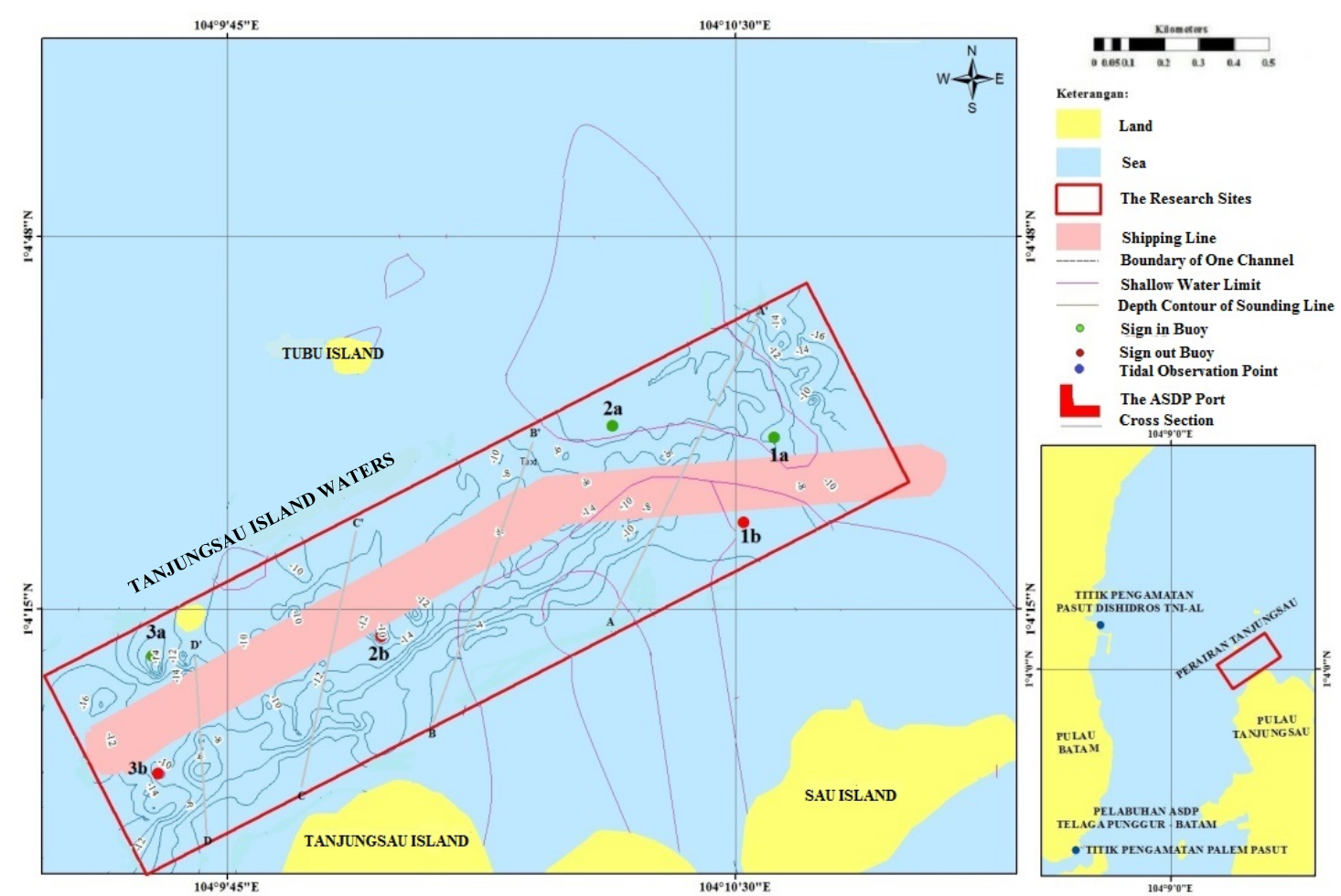

Figure 1. Seabed Slope Zone and ASDP Shipping Line Design in Tanjungsau Island Waters, Batam

Table 3. Van Zuidam Classification of Seabed Slope Calculation

\begin{tabular}{ccccc}
\hline \multirow{2}{*}{ Zone } & Morphology & \multicolumn{2}{c}{ The angle of slope } & Classification \\
& & ()$^{\prime}$ & $\mathbf{( \% )}$ & (Van Zuidam) \\
\hline A-A' & Continental Shelf & 0.91 & 1.58 & Flat to almost flat \\
B-B' & Continental Shelf & 0.68 & 1.19 & Flat to almost flat \\
C-C' & Continental Shelf & 0.62 & 1.08 & Flat to almost flat \\
D-D' & Continental Shelf & 1.48 & 2.59 & Slightly sloping or sloping \\
\hline
\end{tabular}

\section{D Seabed Morphology}

The result of 3D seabed morphology model then overlaid with the contour line and base map of Tanjungsau Island. This 3D seabed morphology model can be seen from two different sides, that is the west and the east side of Tanjungsau Island Waters, Batam.
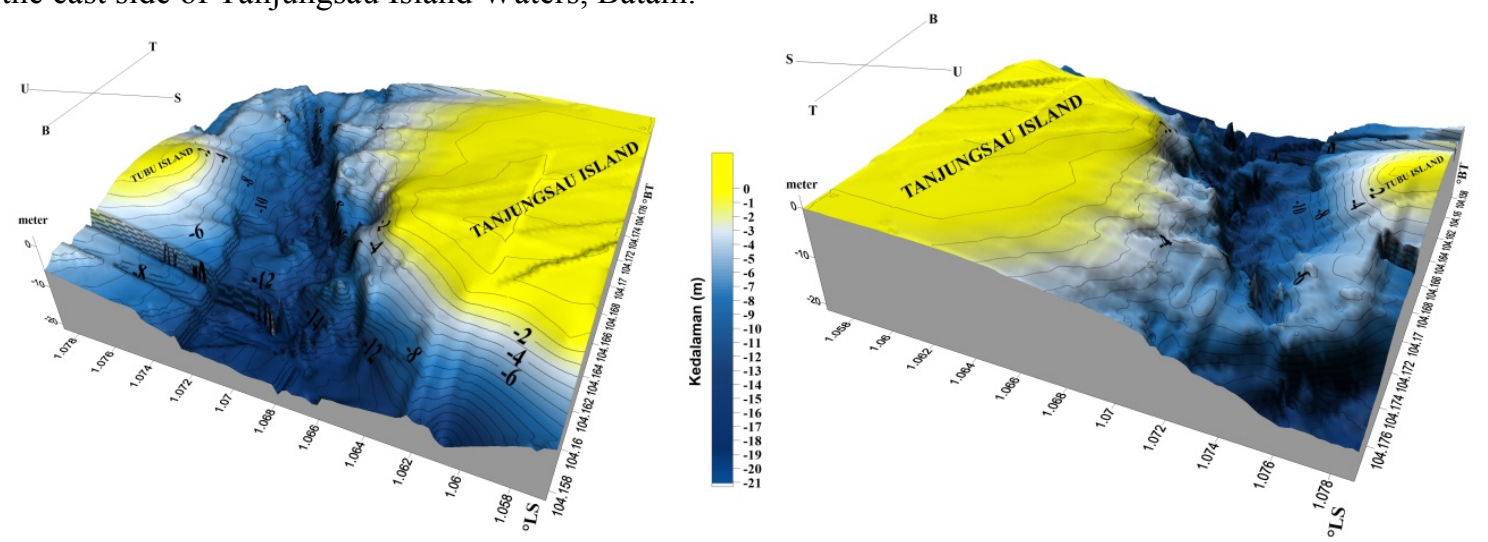

Figure 2. (A) 3D Seabed Morphology Model of West Tanjungsau Island Waters (B) 3D Seabed Morphology Model of East Tanjungsau Island Waters 


\section{Shipping Line}

Based on the consideration of bathymetry recording result in the field, ship draft data and sea map, the determination of approved shipping line use the $5^{\text {th }}$ and $6^{\text {th }}$ horizontal sounding lane with minimum depth of 5.32 $\mathrm{m}$. (Figure 1). So that, the value of UKC is $0.532 \mathrm{~m}$, the maximum draft is $4,788 \mathrm{~m}$ and the width of the shipping line for ASDP vessels minimum $68,025 \mathrm{~m}$.

\section{DISCUSSION}

Tidal

Based on tidal data processing using the Admiralty method, be produced tidal components in the form of Amplitude $(A), M 2, S 2, K 2, N 2, K 1, O 1, M 4$ and $M S 4$. These components obtain a Formzahl value 1,066 which indicates the tidal type of Tanjungsau Island Waters is a dominant semidiurnal mixed tide, happened two times of tide and two times of neap with different height and period in one day. This is confirmed by the statement from Geurhaneu et al. (2016) that tidal reviewed in Batam Waters can be classified as mixed types predominantly semi-diurnal.

Admiralty calculation also produce a neap face $\left(Z_{0}\right)$ with value $159 \mathrm{~cm}$, mean sea level $(M S L)$ as a vertical datum reference $150 \mathrm{~cm}$, the highest high water level $(H H W L) 309 \mathrm{~cm}$, the lowest low water level $(L L W L)-9$ $\mathrm{cm}$. The water height difference at the highest tide and lowest neap is $3.18 \mathrm{~m}$, it should be noted by ships which entering the port.

\section{Bathymetry and Seabed Morphology}

Bathymetry in this research measured by using Echosounder Singlebeam type Ceducer Pro mode High Frequency (HF) which obtained the actual depth in Tanjungsau Island Waters ranging from $-1.69 \mathrm{~m}$ to $-17.58 \mathrm{~m}$. The result of contour map indicate that this area is relatively flat/almost flat, but in the western part of the location there also tightly contour that supposed to be the effect of sandbar. This is confirmed by the statement from Yosi et al. (2012) that distant depth contour pattern shows the seabed slope is relatively sloping, while the tight contour shows a steep slope.

Tanjungsau Island Waters include the continental shelf morphology. In Figure 1 can be seen the depth profile A-A' has a value range $-4 \mathrm{~m}$ to $-17.5 \mathrm{~m}$ with seabed slope $1.72 \%$ which is classified as flat/almost flat. Depth profile B-B' has a value range $-4 \mathrm{~m}$ to $-5.75 \mathrm{~m}$ with seabed slope $1.19 \%$, classified as flat/almost flat. Depth profile $\mathrm{C}-\mathrm{C}^{\prime}$ reached out $-11 \mathrm{~m}$ with seabed slope $1.10 \%$ and still classified flat. The last $\mathrm{D}-\mathrm{D}^{\prime}$ is the deepest profile $-16 \mathrm{~m}$ with seabed score reached out $2.59 \%$ so that includes a slightly sloping. The presence of sandbar at distance about 550 meters from cross-section D-D' supposed to be the effect of industrial waste pollution in the edge of Kabil area which is the southwest of study location. . This is confirmed by statement from Lubis et al. (2017), that sea in Riau Islands includes Batam always get pollution of heavy material that increasing every year. The 3D bathymetry model (Figure 2) made in two sides, the western part of Tanjungsau Island is more sloping than the eastern part. It certainly influenced by geological process that occur in the region (Rahardjo et.al, 2017).

\section{Shipping Line}

The latest data from UPP I Tanjung Uban, the largest draft of ASDP ship that routinely enter the port are $3 \mathrm{~m}$, it is suitable with calculation of the biggest ship draft that can trough the area is $4,788 \mathrm{~m}$. On supporting the shipping line (Figure 1), be assembled navigation aid tools as beacons with special code and flare buoys. Green sign on the left side used to a direction for entering The Port of ASDP Telaga Punggur, while red sign on the right side used to an exit ship guide. In accordance the statement from Triatmodjo (2010) about the placement of groove position determined by assembling buoys with different colors on the right and left sides, where the red buoys in the right and green in the left, so the ship must move between these buoys.

Figure 1 described the direction of ship's appearance must be calculated its distance as far as possible away from dangerous sandbar that only appear when the sea was ebb. This shipping line designed for two lanes with depth value $-5 \mathrm{~m}$ to $-14 \mathrm{~m}$ and a slight bend in the beginning to avoid shallow waters. This is confirmed by statement from Triatmodjo (2010), that making bends often needed on planning of dock layout and the importance of port, with intersection angle from the middle should not exceed 30 degrees or arch radius 4 times longer than the entire ship.

\section{CONCLUSION}

Based on results from this research can be concluded that the depth on Tanjungsau Island Waters is $-1.69 \mathrm{~m}$ to $-17.58 \mathrm{~m}$. Morphology of the seafloor have an enough varied slope, which is the flat/almost flat $1.08 \%-1.58 \%$ until slightly sloping/sloping with slope $2.59 \%$. The shipping line has a minimum depth $-5.32 \mathrm{~m}$ with the maximum ship draft which can enter there $4.788 \mathrm{~m}$. 


\section{REFERENCES}

Central Bureau of Statistics. 2018. The Land Area by The Regency/City. https://kepri.bps.go.id (27 November 2018).

Tanjungpinang I Navigation District. 2018. Disnav Report in June 2018. Tanjungpinang I Navigation District, Riau Islands.

Geurhaneu, N.Y., Susantoro, T. M. 2016. The Change of Coastline in Putri Island Beach-Batam City Using Satellite Image Data year 2000-2016. The Center of Marine Geology Research and Development, Bandung.

Lubis, MZ, Anurogo, W., Khoirunnisa, H., Irawan, S., Gustia, O., Roziqin, A. 2017. Using Side Scan Sonar (SSS) Instrument on Characterizing and Mapping Seabed Identific Targets in Telaga Punggur, Riau Islands, Indonesia. Journal of Geoscience, Engineering, Environmental and Technology 2 (1): pp. 1-8.

Ongkosongo, Otto S.R. 1989. Tides. Indonesian Institute of Oceanology Research and Development Center, Jakarta.

Rahardjo, P., Saputra, M. D. 2017. The Characteristics of Seabed Morphology and Its Relationship with Flow Velocity in Lampa Strait, Natuna, Riau Islands. The Center of Marine Geology Research and Development, Bandung.

Sihombing, A. V. R., Marpaung, N. 2015. The Evaluation of Crossing Existing Performance Telaga PunggurTanjung Uban in Riau Islands. Civil Engineering Department. University of Lampung, Bandar Lampung.

Soeprapto. 2001. Hydrographic Survey. Department of Geodetic Engineering, Faculty of Engineering, Gadjah Mada University, Yogyakarta.

Triatmodjo, B. 2010. The Port Planning. Beta Offset, Yogyakarta.

Yosi, M., Budiona, K., Astario, Prijantono, Nurdin, N., Lubis, S., Godjali, J. 2012. Seabed Geomorphology of Kotok Island Waters, Thousand Islands, Jakarta. Journal of The Center of Marine Geology Research and Development, The Ministry of Energy and Mineral Resources, Bandung.

Zuidam, R. A. V. 1985. Aerial Photo-Interpretation in Terrain Analysis and Geomorphology Mapping. Smith Publisher The Hague, ITC. 